\title{
The Hughesian Legacy: William Shaffir-A Principal Interpreter of the Chicago School Diaspora in Canada
}

\author{
Jacqueline Low \\ University of New Brunswick, Canada
}

DOI: http://dx.doi.org/10.18778/1733-8077.16.2.02

\section{Keywords:}

Herbert Blumer;

George Herbert Mead;

Georg Simmel; Everett

C. Hughes; William

Shaffir; Symbolic

Interactionism;

Fieldwork Method;

The Chicago School;

The Chicago School

Diaspora

\begin{abstract}
In this paper, I discuss the invaluable role played by William Shaffir, my mentor and doctoral supervisor, who shaped my approach to interpretive fieldwork and deepened my understanding of symbolic interactionist theory. Known affectionately as Billy to his colleagues and students, Shaffir is a gifted educator and one of the finest ethnographic researchers of his generation. My focus is on how the scholarly tradition that flows from Georg Simmel through Robert Park, Herbert Blumer, and Everett C. Hughes, passed from Billy on to me, is illustrative of what Low and Bowden (2013) conceptualize as the Chicago School Diaspora. This concept does not refer to the scattering of a people, but rather to how key ideas and symbolic representations of key figures associated with the Chicago School have been taken up by those who themselves are not directly affiliated with the University of Chicago. In this regard, while not a key figure of the Chicago School himself, Shaffir stands at the boundary between the Chicago School of sociology and scholars with no official relationship to the School. As such he is a principal interpreter of the Chicago School Diaspora in Canadian Sociology.
\end{abstract}

Jacqueline Low is a Professor of Sociology at the University of New Brunswick. Her areas of expertise are qualitative methodology, symbolic interactionist theory, the sociology of health, illness, and the body, as well as deviant behavior and social problems. Among her most significant publications are: Structure, Agency, and Social Reality in Blumerian Symbolic Interactionism: The Influence of Georg
Simmel (2008, Symbolic Interaction); The Chicago School Diaspora: Epistemology and Substance (Low and Bowden, 2013, McGill-Queen's University Press); and A Pragmatic Definition of the Concept of Theoretical Saturation (2019, Sociological Focus).

email address: jlow@unb.ca 


\section{William Shaffir-A Principal Interpreter of the Chicago School Diaspora in Canada}

The construct of the Chicago School Diaspora is meant to conceptualize how key ideas and symbolic representations of key figures that people associate with the Chicago School are taken up by scholars unassociated with the University of Chicago. Moreover, the Chicago School Diaspora does not assume a communally held list of scholars or set of ideas. Rather, a core assumption of the construct is the integration into one's "scholarly work" and identity "of what individuals selectively see as insights and key figures they identify with the Chicago School" (Low and Bowden 2013:16). This means that, for some, the Chicago School of sociology might mean George Herbert Mead and Herbert Blumer with a focus on interpretive analysis, while, for others, it may mean Georg Simmel, Robert Park, and Everett C. Hughes, with an emphasis on eclecticism in research methods. As Lofland (1983:491) argues, "the 'Chicago School' is a kind of projective device; descriptions of it seem to reveal as much about those doing the describing as about the phenomenon itself." In this sense, the Chicago School is "like a Swiss Army Knife" made up of an assortment of tools that allow individuals to use it in different ways (Low and Bowden 2013:10).

Given the diversity of key ideas and symbolic representations of key figures associated with the Chicago School of sociology, my intent is not to situate Shaffir as an interpreter of the entirety of the Chicago School tradition. Rather, in explaining his role as a principal interpreter of the Chicago School Diaspora in Canada, I follow the intellectual trail of Simmelian symbolic interactionism (Low 2008) that passed through the prism of Park and Burgess' human ecology perspective (Park 1936) and Hughes' "lively and reflexive conception of research on society as a collective enterprise" (Chapoulie 2016:39), on through Blumer's (1969a) insistence on empirical immersion in research and analysis, and so on through the work of Shaffir and from him, finally to me (see: Figure 1).

\section{Figure 1. William Shaffir: Principal Interpreter of the Chicago School Diaspora.}

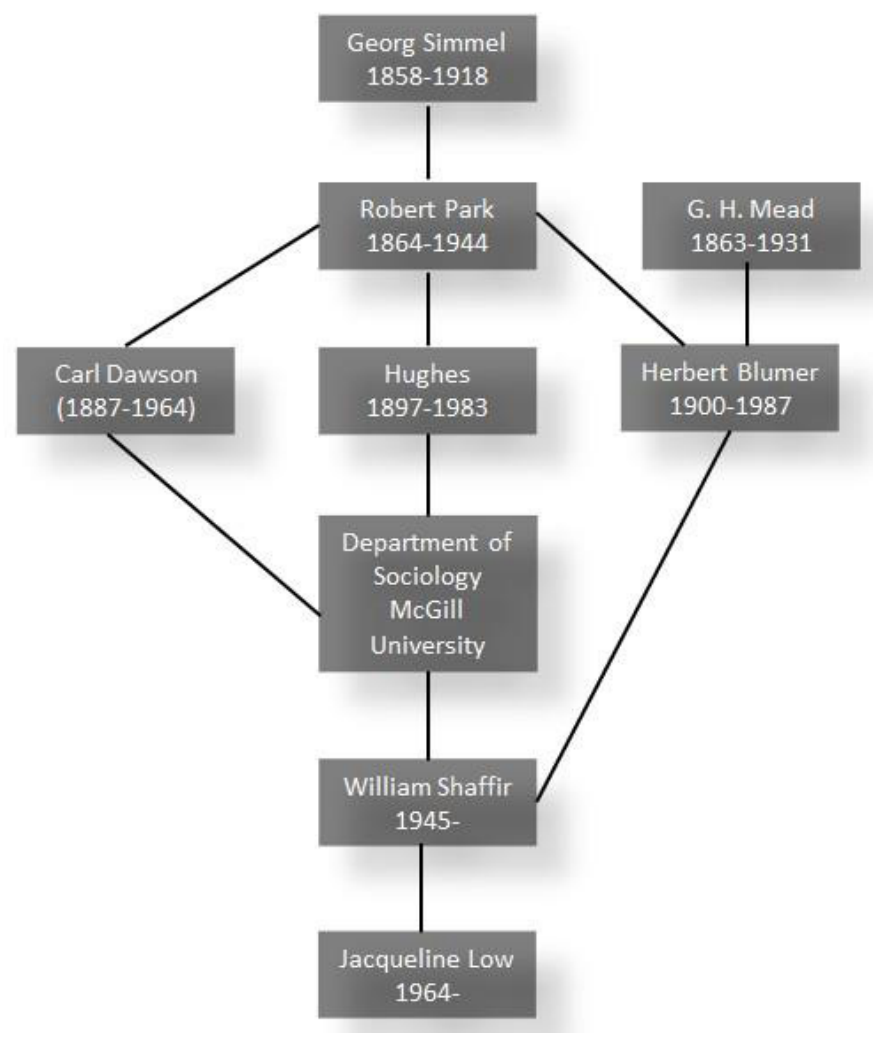

Source: Self-elaboration.

In this way, Shaffir's fieldwork practice, his understanding of symbolic interactionism, and his approach to graduate student supervision have all been fundamentally shaped by the Chicago School 
insights of Everett C. Hughes and Herbert Blumer and, as a result, also by both Georg Simmel and Robert Park, in addition to George Herbert Mead. Thus, Shaffir comes by his status as a principal interpreter of the Chicago School Diaspora more than honestly.

\section{Shaffir and Chicago School Fieldwork}

In 1922, the Department of Sociology at McGill in Montreal was founded by Carl Dawson who was awarded his PhD from the University of Chicago under the supervision of Robert Park and Ernest Burgess (Hoecker-Drysdale 1996; Drysdale and Hoecker-Drysdale 2013; McGill 2019). Consequently, when he arrived at McGill he was, in Campbell and Hall's (1989:334-335) words, "wedded to the human ecology method" and proceeded "as a missionary for the Chicago School of Sociology" in McGill's Department of Sociology. He was followed in the fledgling department by Everett C. Hughes, who was also principally supervised in his doctoral research by Robert Park (Bulmer 2017; McGill 2019), and brought his ethos of fieldwork as the "paramount" method of social science research to the department (Hughes 1961:vi; Manning 2000). The result was that both Dawson and Hughes imbued sociology at McGill with Park's emphasis on the necessity of firsthand observation in fieldwork. In Park's words,

You have been told to go grubbing in the library... to choose problems wherever you can find musty stacks of routine records...prepared by tired bureaucrats and filled out by reluctant applicants for fussy do-gooders or indifferent clerks. This is called "getting your hands dirty in real research." Those who counsel you are wise and honorable...But, one more thing is needful: first-hand observation. Go and sit in the lounges of the luxury hotels and on the doorsteps of flophouses; sit on the Gold Coast settees and the slum shakedowns; sit in Orchestra Hall and in the Star and Garter burlesk [sic]. In short, gentlemen, go get the seat of your pants dirty in real research. [Park as cited in McKinney 1966:71]

Dawson's training in fieldwork at the University of Chicago led him to conduct "a series of outstanding empirical studies" on issues related to ethnic groups, settlers, and immigration (McGill 2019). His skill as an ethnographic field researcher was such that he was the recipient of a prestigious Rockefeller Foundation award in the amount of \$100,000 (McGill 2019). ${ }^{1}$ Hughes brought with him to McGill what Helmes-Hayes (1998:623) characterizes as "interpretive institutional ecology," which he developed through the ethnographic research he conducted for his classic work French Canada in Transition (Hughes 1943). Thus, the Department of Sociology at McGill was fundamentally shaped by a Chicago School emphasis on interpretive theory and empiricism in fieldwork (Ostow 1984; Chekki 1987; Shore 1987; Chapoulie 1996).

William Shaffir was awarded the first doctoral degree in sociology from McGill University in $1972^{2}$ for his ethnographic research on the Chassidic Community in Montreal. ${ }^{3}$ The oral examination of Shaffir's dissertation was judged such an important event that "Everett and Helen Hughes were invited as guests to celebrate" this inaugural doctoral de-

\footnotetext{
${ }^{1}$ This was $\$ 100,000$ in the 1930 's and was at the time "one of the largest grants ever received in sociology in Canada" (McGill 2019).

2 Two dates appear on Shaffir's dissertation: a submission date of 1972 and a copyright date of 1973.

3 The findings from which he published in a series of book chapters and journal articles throughout his career (e.g., Shaffir, Stebbins, and Turowetz 1980; Shaffir 1991; 2000; 2001; 2002; 2004; Brym, Shaffir, and Weinfeld 1993; Shaffir, Dietz, and Stebbins 1994; Shaffir and Bar-Lev 1997).
} 
fense (W. Shaffir, personal communication, May 16, 2018). The fieldwork method used in his doctoral research reflects the strong Chicago School influence provided by Park, Dawson, and Hughes, but also the influence of another key figure of the Chicago School of sociology-Herbert Blumer, also a staunch advocate of naturalistic empirical research. According to Blumer (1969a:44-45):

One goes to the empirical instances of the analytical element, views them in their different concrete settings, looks at them from different positions, asks questions of them with regard to their generic character, goes back and re-examines them, compares them with one another, and in this manner sifts out the nature of the analytical element that the empirical instances represent.

That Shaffir was deeply influenced by the Chicago School tradition is clear from all he has written on fieldwork (e.g., Shaffir, Stebbins, and Turowetz 1980; Shaffir 1991; 2001; Shaffir and Stebbins 1991; 2003; Dietz, Prus, and Shaffir 1994; Shaffir, Dietz, and Stebbins 1994; Pawluch, Shaffir, and Miall 2005) and is most explicitly articulated in an article entitled "Doing Ethnography: Reflections on Finding your Way," which he wrote for the Journal of Contemporary Ethnography (Shaffir 1999). In it he states:

My own position, crystallized over a variety of research, is that the most credible understanding of social phenomena requires the researcher to discover the actor's definition of the situation-that is, his or her perception and interpretation of reality-and that such discovery and understanding are best accomplished by placing oneself in the other person's situation. In my estimation, the participant observation approach of the classical Chicago School best meets this objective. [Shaffir 1999:684-685]
And that tradition is one of empirical examination of the social world, best accomplished by deep immersion into the field of endeavor under study. Putting aside the debates between anthropologists and sociologists as to what rightly constitutes ethnographic research, Shaffir (1999:676) argues that "terminological differences aside," ethnographic fieldwork:

Places researchers in the midst of whatever it is they
study. This vantage point is critical as it enables re-
searchers the best opportunity to examine various
phenomena as perceived by participants. Primari-
ly a process of attempting to describe, analyze, and
interpret social expressions between people and
groups, ethnography requires the researcher to enter
the natural settings for purposes of understanding
the hows, whys, and whats of human behavior.

In other words, ethnographic "fieldwork is carried out by immersing oneself in a collective way of life for the purpose of gaining first-hand knowledge about a major facet of it" (Shaffir and Stebbins 2003:4).

In his long career teaching graduate seminars on qualitative methods and conducting fieldwork, he has published often on critical issues related to qualitative research in general and ethnographic research in particular, such as gaining entrée and leaving the field (Maines, Shaffir, and Turowetz 1980; Shaffir 1991; Shaffir and Stebbins 2003); the importance of relationships with gatekeepers (Haas and Shaffir 1987; Shaffir 1999); the presentation of self and role-taking in research (Shaffir 1969; 1972; 1991; 1999); boundaries between the researcher and the researched (Shaffir et al. 1994; Shaffir 1999); insider/outsider relations in participant observation research (Haas and Shaffir 1987; Shaffir 1999; 
Shaffir and Stebbins 2003); relations with research team members (Shaffir et al. 1980; Haas and Shaffir 1987); issues of validity and reliability (Shaffir and Stebbins 2003); emotions in fieldwork (Haas and Shaffir 1987; Shaffir 1991; Shaffir and Stebbins 2003); and ethics in qualitative research (Shaffir and Stebbins 2003), all of which reflect his deep internalization of Chicago School insights. For instance, Shaffir (1999) has always been deeply concerned with the role of the researcher in fieldwork, and his concern reflects a Hughesian influence. To illustrate, Hughes (1961:vi) writes, "fieldwork...is more than other methods of study, itself a practice...in the perceiving and predicting of social roles, both one's own and those of others" and, likewise, in Shaffir's (1999:681) words, "by its very nature ethnographic research requires some measure of role playing."

\section{Shaffir and Symbolic Interactionism}

Shaffir has been rightly named by McLaughlin (2017) as one of the foremost sociologists carrying on the Blumerian symbolic interactionist legacy in Canada. From his earliest writings, Shaffir identified himself as a symbolic interactionist in the Blumerian school that derives from the insights of George Herbert Mead, Charles Horton Cooley, and W. I. Thomas "and their students," not the least of whom was Herbert Blumer (Shaffir 1972:26). Thus, early in his scholarly career, he took on a version of symbolic interactionism that was shaped by key ideas and key figures of the Chicago School of sociology.

Dawson and Hughes not only brought Chicago School style fieldwork to the Department of Sociology at McGill, they also carried with them their theoretical orientation of symbolic interactionism. Principally, they brought the collective insights of several key figures of the Chicago School, including not only George Herbert Mead, but also George Simmel, Robert Park, and Everett Hughes. These insights combined to create what can be rendered as Blumerian symbolic interactionism with a Hughesian twist (Blumer 1969a; 1969b; Low 2008). These insights are implicit or explicit in all of Shaffir's research and writing.

This variant of symbolic interactionism understands society as the product of interaction. For instance, Simmel argues that "individuals...form a unity, that is, a society...For unity in the empirical sense is nothing but the interaction of elements" (Simmel as cited in Levine 1988:23). Similarly Park (1915:578), himself a student of Simmel (University of Chicago 2019), writes about the city - the base structure of society-in much the same way:

What we ordinarily regard as the city-its charters, formal organization, buildings, street railways, and so forth-is, or seems to be, mere artifact. However, it is only when and in so far as these things, through use and wont, connect themselves, like a tool in the hand of a man, with the vital forces resident in individuals and in the community that they assume the institutional form.

Likewise Hughes, who was a student of both Park and Simmel, followed a form of symbolic interactionism that Helmes-Hayes (1998:623) characterizes as "interpretive institutional ecology," a perspective shaped by "classical Chicago sociology...anthropological functionalism and Simmel's formalism." Later writing with Simmel, he also expresses that society is the sum total of interaction. In their words, "the impulses and interests, which a man experiences in himself and which push him out toward other men, bring about all the forms of association by 
which a mere sum of separate individuals are made into a 'society'"' (Simmel and Hughes 1949:254). And for Blumer (1969b:20, 85), who was as much influenced by Simmel, Park, and Hughes as he was by Mead (Rock 1979; Low 2008; Smith 2017), society is "people engaged in living...they are caught up in a vast process of interaction in which they have to fit their developing lines of action to one another... there is no empirically observable activity in human society that does not spring from some acting unit." Even Mead (1962) himself, who is known almost exclusively for his overwhelming focus on mind and self rather than on society, sees the latter as the sum of interaction. He writes "Social institutions, like social selves, are developments within, or particular and formalized manifestations of, the social life-process" (Mead 1962:262). And it is this central understanding of society that is evoked in Shaffir's (1972:22) dissertation when he cites Warren's definition of society as "structures of interaction which endure through time and can be recognized as entities in their own right" (Warren 1963:46). It can also be seen in his selection of the community as the unit of analysis he used in his doctoral research (Shaffir1972).

Shaffir has always stressed the Meadian emphasis within symbolic interactionist theory. As he writes in his dissertation, "The chief focus of this social psychology, known as symbolic interaction, is that interaction as it occurs among human beings consists in that they do not merely react to each other's actions, but rather interpret or define each other's actions before they act" (Shaffir 1972:25-26). Similarly, how individuals in interaction come to a "definition of the situation" through the meanings they share has been an ongoing concern (Thomas 1923:xv). For instance, Haas and Shaffir (1987:114) write "symbolic interactionism underlies our theoretical anal- ysis and takes, as a given, that the understanding of human conduct requires a consideration of the meanings and definitions which evoke conduct." And later still, Shaffir concludes that his "own position crystallized over a variety of research is that the most credible understanding of social phenomena is to discover the actor's definition of the situation-that is, his or her perception and interpretation of reality" (Shaffir 1999:677, 684-685). He makes this point more explicitly in writing with Dorothy Pawluch about the use of symbolic interactionism in studies of occupations and professions. In their words:

rather than focusing on the objective characteristics of occupations and their interrelationships and place in the larger social structure, symbolic interactionists view occupations subjectively as groups of workers constructing meanings: deciding who they are and what they are about; what services they should be providing and to whom; dealing with issues that come up with their clients, other occupations, and the society within which they work; and responding to changes in their environment and in the circumstances of their work. [Shaffir and Pawluch 2003:894]

Notwithstanding the above, it would be a mistake to assume that because of this emphasis on how individuals construct meaning Blumerian symbolic interactionism cannot, and that Shaffir does not, address social structural concerns (Maines and Morrione 1991). Rather, Simmel argues that as social forms "crystallize, they attain their own existence and their own laws, and may even confront or oppose spontaneous interaction" (Simmel as cited in Wolff 1964:10). Likewise, Blumer (1980:410) writes, "there is a world of reality 'out there' that stands over against human beings and that is capable of resisting actions toward it." And a distinctly Hughesian, and 
therefore Simmelian, strain of Blumerian symbolic interactionism is also evident in Shaffir's analyses in the importance he places on the building blocks of social structure: institutions, roles, "stratification systems...social class and status-group membership" (Haas and Shaffir 1978:20), as well as the necessity of understanding "human action [as] inseparable from its context" (Haas and Shaffir 1987:115). To illustrate, while Chapoulie (1996:20) argues that Hughes' attention to social structure and historical context has been "largely ignored" by later generations of sociologists, Haas and Shaffir (1987) "cite Hughes more than any other scholar" in their classic ethnography Becoming Doctors (Low and Bowden 2016:121). And in its methodological appendix they demonstrate their attention to social structural issues when they argue "for an occupation to achieve professional status, it must be granted legitimacy by whatever audience...is crucial to such status passage. The audience may include clients, 'public,' or the state" (Haas and Shaffir 1987:115). In the same way, the importance of institutions, as the large building blocks of social structure, is also demonstrated. In their words: "in modern industrial society, the professional school as part of a scientifically based university becomes the critical legitimating institution" (Haas and Shaffir 1987:4; cf. Shaffir, Rosenberg, and Haas 2004).

\section{Shaffir and the Transmission of Ideas}

The final way in which Shaffir is a principal interpreter of the Chicago School Diaspora in Canada is manifest in his "master status" as a professor (Hughes 1945:357). Shaped by the insights of key figures of the Chicago School that coalesced into a fusion of Blumerian and Hughesian influences, Shaffir developed into a sociologist deeply committed to empirical research and the interpretivist un- derstanding of everyday life. It was this scholarly tradition that shaped how Shaffir played the roles of professor and supervisor. And it was this same scholarly tradition that he interpreted and transferred to me as a doctoral student at McMaster University. In this regard, I see a resonance between key aspects of Hughes and Shaffir's teaching and supervisory styles.

The first point of resonance I see is in how both Hughes and Shaffir approached the teaching of qualitative methods. For instance, Hughes once had to radically alter a course he was given in order to achieve his goal of teaching fieldwork methods. According to Heath (1984:222), when early in his tenure at the University of Chicago, Hughes was assigned "a first-year introductory course in sociology...[he]... turned it into an introduction to fieldwork. Within the course students were encouraged to conduct small scale empirical exercises." Likewise, Shaffir re-designed the graduate qualitative methods course I took with him at McMaster University to focus on ethnographic fieldwork methods; to the exclusion of other forms of qualitative methodology. ${ }^{4}$ As students in that seminar, we were likewise tasked with conducting small scale fieldwork studies. I remember my fellow doctoral student, Joey Moore, saying at the time that the seminar should have been called "Fieldwork Methods," not "Qualitative Methods," which was a disappointment to him because he had been hoping to learn about historical analysis (personal communication, September 1992). It was not a disappointment to me. Having read Blumer's (1969a) Symbolic Interaction Perspective and Method as an undergraduate student, I was eager to learn more about Chicago School style field research.

\footnotetext{
${ }^{4}$ A focus that has remained throughout his teaching of this graduate seminar at McMaster (cf. Shaffir 2017).
} 
For this seminar, I conducted research on how students with disabilities negotiated disabled and non-disabled identities while negotiating the physical environment of the university campus. However, that was not the first topic I chose to research. Because of my mother's many years of struggle with serious chronic illness and disability which necessitated several hospitalizations, my first thought had been to conduct observational research in emergency department waiting rooms. In discussing challenges from his own dissertation research in seminar, Billy demonstrated how difficult it would be for me to gain entrée to such a setting, leading me to change the focus of my study to the topic of students with disabilities. This was an important change in terms of my career progression as I was later able to publish the findings of this field study in an article that has become one of my most cited works (Low 1996).

Also, as part of this seminar, Billy taught us to interview and make verbatim notes without the aid of audio-recording, a discipline I have retained throughout my scholarly career and one that has benefited me in a myriad of ways. In the first instance, it allowed me to have informal conversations with students with disabilities without the distraction of overt note-taking or audio-recording. Moreover, Billy emphasized the importance of the setting in ethnographic research throughout the seminar. This led me to pay attention to the university campus in a way that I otherwise would not have done and which enriched the theoretical depth of my analysis as it enabled me to examine the connections between space, place, and identity (Low 1996).

Later in the seminar, when students brought in field notes for Billy to comment on, he said only one word to me, "identity," providing me with the conceptual basis for my analysis. He later suggested I read Scott's (1969) The Making of Blind Men, which, in turn, led me to Davis (1961) on deviance disavowal. All of this helped me to conceptualize the means used by the students I spoke with to manage the stigma they experienced as people living with a disability. It also led me to choose the area of deviant behavior for one of my comprehensive exams that furthered my on-going interest in stigma and stigma management, and influenced how I teach social problems (Low 2000; 2004; 2005; 2007; 2018).

Billy also taught us the invaluable lesson that "qualitative researchers count"; they count frequencies of observations, events, stages in processes, and so on (Corbin and Strauss 1990; W. Shaffir, personal communication, September 1992). Understanding that numbers matter in qualitative analysis allowed me to address a central question in my doctoral research, namely, why do people use alternative therapies? For instance, in the literature on the lay use of these approaches to health and healthcare, a desire for control over health and healing was commonly cited as a key motivating factor. In contrast, I found that only one out of the 21 informants I interviewed said that a desire for control over their healing process led them to first choose alternative therapies. This enabled me to argue that the generic social process of problem solving, not individual motivating factors, better explained informants' health-seeking behavior (Low 2004). Later in my career, counting frequencies allowed me to explain why, in my research with seniors, informants in the 80-84 age range made more statements of ability than those in younger age ranges. The explanation lay in counting the number of seniors who still drove or had other access to independent means of transportation (Low 2015). 
Another point of correspondence between Hughes and Shaffir concerns their teaching styles. More than one contemporary of Hughes has noted that his teaching style was not for all students. For example, Riesman (1983:478) recalls that students "were turned off by Everett. He was never charismatic; his lectures were discursive and wandering, following the question where it led. He did not make it easy for students to take notes nor to predict what they might be asked in an examination." Similarly Weiss (1996:543) remembers that "Everett's teaching style required his classes to think along with him. Everett would discuss a topic by providing...stories, anecdotes, and observations, one following another... Often most of a class would miss the underlying thread." Billy taught in a similarly discursive and anecdotal manner. His lectures were replete with insights and anecdotes from his fieldwork, a practice made plain when he instructed me and his other eleven teaching assistants that he would "teach the course" and we would "teach the text book" (personal communication, September 1992).

A final similarity I see between Hughes and Shaffir regards their relatively light touch as supervisors. Hughes "was not directive with his students" (Helmes-Hayes 1998:632; Vienne 2010; 2016). For example, Becker and Riesman (2017:vii) relate how “When Becker was preparing his first scholarly article, based on his master's thesis, Everett advised him to...take one idea, attach everything in the thesis to it that would stick and leave the rest out." Guidance almost identical in essence, if not exactly in substance, to the advice Billy gave me when I asked him how to go about publishing a paper based on the field work report I wrote for his qualitative methods seminar. When we met for coffee to discuss publishing, he began turning over the pages of the report saying, "you take some of this, and you take some of that, and forget about the rest" (W. Shaffir, personal communication, May 2003).

Thus, despite Hughes' "discursive" style, Riesman (1983:478) notes that he "sent many gifted individuals off along the many lines of their interests and his own" and likewise, with that one word "identity," Billy provided me with the key to my analysis and an abiding interest in this concept (Haas and Shaffir 1978; Low 1996). In this way, students of Hughes "took up his ideas via a process more akin to 'osmosis' than tutelage" (Helmes-Hayes 1998:632) and the same kind of process of osmosis was operative in how ideas passed through Billy to me. But oh the invaluable things I learned through this process. I owe to him my understanding of fieldwork methods that informs both my research practice and my teaching of graduate level qualitative methods. Echoing Park, as well as Hughes, Billy charged me to "go do," instead of blinding myself with too deep a reading of the literature before going out into the setting to engage in naturalistic enquiry, as Simmel, Park, Blumer, Dawson, and Hughes did before him. Reflective of Hughes' methodological eclecticism (Heath 1984:222), Billy used survey questionnaires as part of his participant observation in the Chasidic community, passing on to me an openness to the use of numbers in qualitative analyses.

Finally, but of no less importance, Billy encouraged me to present my work at the Qualitative Analysis Conference. The conference, affectionately known as The Qualitatives, has been going strong for 36 years, training successive generations of qualitative researchers. Billy was a founding member of the small group of Canadian and US sociologists who began the conference in 1984 to provide a supportive environment where people interested in using a symbolic interactionist perspective and ethnographic 
method in analyses of deviant behavior could share their research without positivist criticism. In his characteristically understated way, I remember Billy saying to me, "you should present your paper at this thing, it would be good" (W. Shaffir, personal communication, February 1993), and it was. It was more than good because attending the conference year after year enabled me to hear premier symbolic interactionists and ethnographers give papers, including Shaffir himself, as he demonstrated his own brand of Blumerian interactionism.

It was also good because as a faculty member in the Department of Sociology at the University of New Brunswick, I have had the pleasure of organizing The Qualitatives twice, and was deeply honored to host the $25^{\text {th }}$ anniversary of the conference, again, demonstrating the passage of ideas from the Chicago School, through Billy to me. To illustrate, Nels Anderson, author of The Hobo, the first fieldwork monograph of the Chicago School of sociology, ended his career in sociology at UNB. As such, the decision was made to feature Anderson's career as an important part of the conference, providing me with the opportunity to read deeply about the history of the Chicago School and to later publish an edited volume, The Chicago School Diaspora: Epistemology and Substance, based on papers from the conference that celebrates the Chicago School legacy (Low and Bowden 2013). This had an ongoing

\section{References}

Becker, Herbert and David Riesman. 2017. "Introduction to the Transaction Issue." Pp. v-xiv in The Sociological Eye (Social Science Classics Series), by E. C. Hughes. New York: Routledge Press.

Blumer, Herbert. 1969a. Symbolic Interactionism: Perspective and Method. Englewood Cliffs, NJ: Prentice Hall. impact on my career because of the strength of both these experiences, Gary Bowden and I were invited to write a chapter on Everett C. Hughes and his influence on Canadian sociology (Low and Bowden 2016) and to other papers on the status and future of symbolic interactionist theory in Canada (Low 2017; 2018). Further, in hosting The Qualitatives for the second time this year, we featured a special session in honor of the $50^{\text {th }}$ anniversary of the publication of Blumer's (1969a) Symbolic Interaction: Perspective and Method in the program. We will publish a special issue dedicated to this theme in the journal Symbolic Interaction, aiding in the perpetuation of the Chicago School tradition.

In the end, it is the Simmelian, Meadian, Hughesian, and Blumerian legacy that connects the Chicago School to me through Billy as my supervisor. This supervisory relationship is therefore central to how key ideas of the Chicago School tradition are interpreted, passed on, and given new life among scholars not directly related to the Chicago School, enhancing our understanding about how ideas in general are transmitted (c.f. Low 2008; 2018; Low and Bowden 2013; 2016). Thus, it has been through his teaching, publishing, and supervision that Shaffir, like Hughes, has trained further generations of interpretivist qualitative researchers who carry on the legacy of Chicago School fieldwork, making him a principal interpreter of the Chicago School Diaspora in Canada.
Blumer, Herbert. 1969b. "Fashion: From Class Differentiation to Collective Selection." Sociological Quarterly 10:275-291.

Blumer, Herbert. 1980. "Mead and Blumer: The Convergent Methodological Perspectives of Social Behaviorism and Symbolic Interactionism." American Sociological Review 45:409-419. 
Brym, Robert, William Shaffir, and Morton Weinfeld (eds.). 1993. The Jews in Canada. Toronto: Oxford University Press.

Bulmer, Martin. 2017. "Robert Park's Journey into Sociology." Pp. 37-49 in The Anthem Companion to Robert Park, edited by P. Kivisto. London: Anthem Press.

Campbell, Douglas F. and Oswald Hall. 1989. "Review Symposium: Sociologists Examine a Historian's Account of the Development of Social Research at McGill." Canadian Review of Sociology and Anthropology 26(2):333-335.

Chapoulie, Jean-Michel. 1996. "Everett Hughes and the Chicago Tradition." Sociological Theory 14(1):3-29.

Chapoulie, Jean-Michel. 2016. "Everett Hughes and the Chicago Tradition." Pp. 39-69 in The Anthem Companion to Everett C. Hughes, edited by R. Helms-Hayes and M. Santoro. London: Anthem Press.

Chekki, Dan A. 1987. American Sociological Hegemony: Transnational Explorations. Lanham, MD: University Press of America.

Corbin, Juliet M. and Anselm L. Strauss. 1990. "Grounded Theory Research: Procedures, Canons, and Evaluative Criteria." Qualitative Sociology 13(1):3-21.

Davis, Fred. 1961. "Deviance Disavowal: The Management of Strained Interaction by the Visibly Handicapped." Social Problems 9:120-140.

Dietz, Mary Lorenz, Robert Prus, and William Shaffir (eds.). 1994. Doing Everyday Life: Ethnography as Human Lived Experience. Toronto: Copp Clark Longman.

Drysdale, John and Susan Hoecker-Drysdale. 2013. “The History of Sociology: The North American Perspective." Pp. 28-44 in 21st Century Sociology, edited by C. D. Bryant and D. L. Peck. Thousand Oaks, CA: Sage Publications.

Haas, Jack and William Shaffir. 1978. Shaping Identity in Canadian Society. Scarborough, ON: Prentice Hall.

Haas, Jack and William Shaffir. 1987. Becoming Doctors: The Adoption of a Cloak of Competence. Greenwich, CT: JAI Press.

Heath, Christian. 1984. "Everett Cherrington Hughes (18971983): A Note on His Approach and Influence." Sociology of Health and Illness 6(2):218-237.

Helmes-Hayes, Richard C. 1998. "Everett Hughes: Theorist of the Second Chicago School." International Journal of Politics, Culture and Sociology 11(4):621-643.
Hoecker-Drysdale, Susan. 1996. "The Careers of Helen MacGill Hughes and Everett Cherrington Hughes." Pp. 220-231 in Creative Couples in the Sciences, edited by H. M. Pycior, N. G. Slack, and P. G. Abir-Am. New Brunswick, NJ: Rutgers University Press.

Hughes, Everett C. 1943. French Canada in Transition. Chicago: University of Chicago Press.

Hughes, Everett C. 1945. "Dilemmas and Contradictions of Status." American Journal of Sociology 50(5):353-359.

Hughes, Everett C. 1961. "Introduction: The Place of Fieldwork in the Social Sciences." Pp. v-xiv in Fieldwork: An Introduction to the Social Sciences, edited by B. H. Junker. Chicago: Chicago University Press.

Levine, Donald N. (ed.). 1988. Georg Simmel: On Individuality and Social Forms. Chicago: Chicago University Press.

Lofland, Lyn. H. 1983. “Understanding Urban Life: The Chicago Legacy." Journal of Contemporary Ethnography 11(4):491-511.

Low, Jacqueline. 1996. “Negotiating Identities, Negotiating Environments: An Interpretation of the Experiences of Students with Disabilities." Disability and Society 11(2):235-248.

Low, Jacqueline. 2000. "Managing Stigma via Retrospective Reinterpretation: An Analysis of Individuals' Accounts of Why They Use Alternative Therapies." Paper presented at the BSA Medical Sociology Group and the European Society of Health \& Medical Sociology Association Joint Conference. September 14-17, York, UK.

Low, Jacqueline. 2004. Using Alternative Therapies: A Qualitative Analysis. Toronto: Canadian Scholars' Press.

Low, Jacqueline. 2005. "Avoiding the Other: A Technique of Stigma Management among People Who Use Alternative Therapies." Pp. 273-285 in Doing Ethnography: Researching Everyday Life, edited by D. Pawluch, W. Shaffir, and C. Miall. Toronto: Canadian Scholars' Press.

Low, Jacqueline. 2007. “Avoiding Secondary Deviance: Modes of Stigma Management among Users of Alternative and Complementary Therapies." Paper presented at the Society for the Study of Social Problems 57th Annual Meeting Research Matters: Creating Knowledge, Policy, and Justice. August 10-12, New York, US.

Low, Jacqueline. 2008. "Structure, Agency, and Social Reality in Blumerian Symbolic Interactionism: The Influence of Georg Simmel." Symbolic Interaction 31(3):325-343. 
Low, Jacqueline. 2015. "Seniors Accounts of Ability and Inability." Paper presented at the Brown Bag Talk Series. January 19, Department of Sociology, University of New Brunswick, Fredericton, New Brunswick, Canada.

Low, Jacqueline. 2017. “Whither Symbolic Interactionism in Canada? A Response to Helmes-Hayes and Milne's 'The Institutionalization of Symbolic Interactionism in Canadian Sociology."' Canadian Journal of Sociology 42(2):197-202.

Low, Jacqueline. 2018. "Symbolic Interactionism in Canada: Shared Meaning and the Perpetuation of Ideas." Symbolic Interaction 42(3):468-481.

Low, Jacqueline and Gary Bowden (eds.). 2013. The Chicago School Diaspora: Epistemology and Substance. Montreal: McGill-Queens University Press.

Low, Jacqueline and Gary Bowden. 2016. "Everett C. Hughes: A Key Figure of the Chicago School Diaspora." Pp. 115-131 in The Anthem Companion to Everett C. Hughes, edited by R. HelmsHayes and M. Santoro. London: Anthem Press.

Maines, David R. and Tom J. Morrione. 1991. “Social Causation and Interpretive Processes: Herbert Blumer's Theory of Industrialization and Social Change." International Journal of Politics, Culture, and Society 4(4):535-547.

Maines, David R., William Shaffir, and Alan Turowetz. 1980. "Leaving the Field in Ethnographic Research." Pp. 261-280 in Fieldwork Experience: Qualitative Approaches to Social Research, edited by W. Shaffir, R. A. Stebbins, and A. Turowetz. New York: St Martin's Press.

Manning, Geraldine A. 2000. "Everett Cherrington Hughes: Sociologist and Mentor Sui Generis." The American Sociologist Winter:93-99.

McGill. 2019. “Our History, McGill University Sociology Website." Retrieved March 04, 2019 (https://www.mcgill.ca/sociology/aboutus).

McKinney, John C. 1966. Constructive Typology and Social Theory. New York: Appleton-Century-Crofts.

McLaughlin, Neil. 2017. "Movements, Sects and Letting Go of Symbolic Interactionism." Canadian Journal of Sociology 42(3):203-209.

Mead, George H. 1962. Mind, Self, and Society: From the Standpoint of a Social Behaviorist. Chicago: University of Chicago Press.
Ostow, Robin 1984. "Everett Hughes: The McGill Years." Society-Société 8:3:12-16.

Park, Robert E. 1915. “The City: Suggestions for the Investigation of Human Behavior in the City Environment." American Journal of Sociology 20(5):577-612.

Park, Robert E. 1936. "Human Ecology." American Journal of Sociology 42(1):1-15.

Pawluch, Dorothy, William Shaffir, and Charlene Miall (eds.). 2005. Doing Ethnography: Studying Everyday Life. Toronto: Canadian Scholars' Press.

Riesman, David. 1983. “The Legacy of Everett C Hughes." Contemporary Sociology 12(5):447-481.

Rock, Paul. 1979. The Making of Symbolic Interactionism. Totowa, NJ: Rowman and Littlefield.

Scott, Robert A. 1969. The Making of Blind Men. New York: Russell Sage Foundation.

Shaffir, William. 1969. "The Montreal Chassidic Community: Community Boundaries and the Maintenance of Ethnic Identity." Master's Thesis, Department of Sociology, McGill University, Montreal. Retrieved April 13, 2019 (http://digitool. library.mcgill.ca/R/-?func=dbin-jump-full\&amp;current_ base $=$ GEN01\&amp; objectid=155954).

Shaffir, William. 1972. "Life in an Urban Chassidic Community: Insulation and Proselytization." PhD Dissertation, Department of Sociology, McGill University, Montreal. Retrieved April 13, 2019 (http://digitool.library.mcgill.ca/R/?func=dbin-jump-full\&amp;current_base=GEN01\&amp; objectid=155954).

Shaffir, William. 1991. "Managing a Successful Self-Presentation: Some Personal Reflections on Entering the Field." Pp. 72-81 in Experiencing Fieldwork: An Inside View of Qualitative Research, edited by W. B. Shaffir and R. A. Stebbins. Newbury Park, CA: Sage Publications.

Shaffir, William. 1999. "Doing Ethnography: Reflections on Finding Your Way." Journal of Cotemporary Ethnography 28(6):676-686.

Shaffir, William. 2000. "Movements In and Out of Orthodox Judaism: The Cases of Penitents and the Disaffected." Pp. 269-285 in Joining and Leaving Religion: Research Perspectives, edited by L. J. Francis and Y. J. Katz. Trowbridge, Waltshire: Gracewing. 
Shaffir, William. 2001. "Fieldwork among Hassidic Jews: Moral Challenges and Missed Opportunities." The Jewish Journal of Sociology 43(1\&2):53-69.

Shaffir, William. 2002. "Outremont's Hassidim and Their Neighbours: An Eruv and Its Repercussions." The Jewish Journal of Sociology 44(1\&2):56-71.

Shaffir, William. 2004. "Secular Studies in a Hassidic Enclave: 'What Do We Need It For?'” The Jewish Journal of Sociology 46(1\&2):59-77.

Shaffir, William. 2017. Qualitatives Methods, SOCIOL 742, Course Outline, Department of Sociology, McMaster University, Hamilton, Ontario, Canada.

Shaffir, William and Mordechai Bar-Lev (eds.). 1997. Leaving Religion and Religious Life. Greenwich, CT: JAI Press.

Shaffir, William and Dorothy Pawluch. 2003. "Occupations and Professions." Pp. 893-913 in Handbook of Symbolic Interactionism, edited by L. T. Reynolds and N. J. Herman-Kinney. Lanham, MD: AltaMira Press.

Shaffir, William and Robert Stebbins (eds.). 1991. Experiencing Fieldwork: An Inside View of Qualitative Research. Newbury Park, CA: Sage Publications.

Shaffir, William and Robert Stebbins. 2003. "Introduction to Fieldwork." Pp. 2-16 in Qualitative Approaches to Criminal Justice: Perspectives from the Field, edited by M. R. Pogrebin. Thousand Oaks, CA: Sage.

Shaffir, William, Mary Lorenz Dietz, and Robert Stebbins. 1994. "Field Research as Social Experience: Learning to do Ethnography." Pp. 30-54 in Doing Everyday Life: Ethnography as Human Lived Experience, edited by M. L. Dietz, R. Prus, and W. Shaffir. Toronto: Copp Clark Longman.

Shaffir, William, Michael Rosenberg, and Jack Haas. 2004. "Socialization." Pp. 79-103 in New Society, $4^{\text {th }}$ edition, edited by R. Brym. Toronto: Harcourt Brace.
Shaffir, William, Robert A. Stebbins, and Alan Turowetz (eds.). 1980. Fieldwork Experience: Qualitative Approaches to Social Research. New York: St Martin's Press.

Shore, Marlene. 1987. The Science of Social Redemption: McGill, the Chicago School, and the Origins of Social Research in Canada. Toronto: University of Toronto Press.

Simmel, Georg and Everett C. Hughes. 1949. "The Sociology of Sociability." The American Journal of Sociology 55(3):254-261.

Smith, Greg. 2017. “Georg Simmel: Interactionist before Symbolic Interactionism." Pp. 41-70 in The Interactionist Imagination, edited by M. H. Jacobsen. London: Palgrave MacMillan.

Thomas, William I. 1923. The Unadjusted Girl. Boston: Little, Brown, and Company.

University of Chicago. 2019. “The University of Chicago Centennial Catalogues, The University of Chicago Faculty: A Centennial View." Retrieved April 13, 2019 (https://www. lib.uchicago.edu/projects/centcat/fac/facch17_01.html).

Vienne, Phillippe. 2010. “The Enigma of the Total Institution: Rethinking the Hughes-Goffman Intellectual Relationship." Sociologica 2:1-30.

Vienne, Phillippe. 2016. "The Natural History of Everett Cherrington Hughes: A Master of Fieldwork." Pp. 93-114 in The Anthem Companion to Everett Hughes, edited by R. HelmesHayes and M. Santoro. London: Anthem Press.

Warren, Roland L. 1963. The Community in America. Chicago: Rand McNally and Company.

Weiss, Robert S. 1996. "Remembrance of Everett Hughes." Qualitative Sociology 19(4):543-551.

Wolff, Kurt H. (ed. \& trans.). 1964. The Sociology of Georg Simmel. New York: The Free Press.

\section{Citation}

Low, Jacqueline. 2020. "The Hughesian Legacy: William Shaffir-A Principal Interpreter of the Chicago School Diaspora in Canada." Qualitative Sociology Review 16(2):14-26. Retrieved Month, Year (http://www.qualitativesociologyreview.org/ENG/archive_eng.php). DOI: http://dx.doi.org/10.18778/1733-8077.16.2.02 